\title{
REVIEW
}

\section{Host specificity and dispersal strategy in gyrodactylid monogeneans, with particular reference to Gyrodactylus salaris (Platyhelminthes, Monogenea)}

\author{
Tor A. Bakke ${ }^{1}$, Phil. D. Harris ${ }^{2}$, Peder A. Jansen ${ }^{1}$, Lars P. Hansen ${ }^{3}$ \\ ${ }^{1}$ Zoological Museum, University of Oslo, Sars gate 1, N-0562 Oslo 5, Norway \\ ${ }^{2}$ Department of Biochemistry, 4W, University of Bath, Claverton Down, Bath BA2 7AY, UK \\ ${ }^{3}$ Norwegian Institute for Nature Research, Tungasletta 2, N-7004 Trondheim, Norway
}

\begin{abstract}
Gyrodactylus salaris Malmberg, 1957 is an important pathogen in Norwegian populations of Atlantic salmon Salmo salar. It can infect a wide range of salmonid host species, but on most the infections are probably ultimately limited by a host response. Generally, on Norwegian salmon stocks, infections grow unchecked until the host dies. On a Baltic salmon stock, originally from the Neva River, a host reaction is mounted, limiting parasite population growth on those fishes initially susceptible. Among rainbow trouts Oncorhynchus mykiss from the same stock and among full sib anadromous arctic char Salvelinus alpinus, both naturally resistant and susceptible individuals later mounting a host response can be observed. This is in contrast to an anadromous stock of brown trout Salmo trutta where only innately resistant individuals were found. A general feature of salmonid infections is the considerable variation of susceptibility between individual fish of the same stock, which appears genetic in origin. The parasite seems to be generally unable to reproduce on non-salmonids, and on cyprinids, individual behavioural mechanisms of the parasite may prevent infection. Transmission occurs directly through host contact, and by detached gyrodactylids and also from dead fishes. Relative importance of these routes and of different host species in the epidemiology of the disease is discussed with reference to laboratory experiments and existing knowledge concerning the host-parasite ecology.
\end{abstract}

\section{INTRODUCTION}

Monogeneans of the genus Gyrodactylus are common parasites of freshwater and marine fishes. Although well known as pathogens of farmed fishes (Malmberg 1957, 1989a, b, Bauer 1958, 1988, Cone et al. 1983, Musselius 1988, Solomatova \& Luzin 1988), they are believed to do little direct harm in natural infections. The present epidemic of G. salaris Malmberg, 1957 on wild Atlantic salmon Salmo salar L. along the Atlantic seaboard of Norway is therefore quite exceptional (Anonymous 1990). Over the past 15 yr severe mortality of young salmon due to $G$. salaris has been reported from many rivers (Johnsen \& Jensen 1985.
1986,1988 ) and this has been held responsible for declines of up to $520 \mathrm{t}$ [20\% of the total catch; see Dolmen (1987) and Mo (1989)] per year in catches of adult salmon returning to the rivers to spawn. The ecological impact of the parasite, and of measures aimed at its control, is considerable (Johnsen \& Jensen 1991); at present salmon from a number of Norwegian rivers are being eradicated using rotenone prior to restocking with disease-free stock (Johnsen et al. 1989).

Little is known of the epidemiology of Gyrodactylus salaris in Norway (see Johnsen \& Jensen 1991). Gyrodactylids are unusual in being viviparous (Harris 1988a) and can transfer freely between hosts as adults. The population dynamics of gyrodactylids are therefore 
more characteristic of bacterial and protozoan microparasites than of metazoan pathogens (Anderson \& May 1978, Scott \& Anderson 1984). High fish mortality and high parasite abundance is seen in salmon parr before they migrate to the sea, but other stages in the life cycle (smolts, precocious males, returning adults) and other fish species can support the parasite and may play a part in its transmission. Fish vary, both between and within species, in their susceptibility and response to Gyrodactylus infection. An understanding of the processes involved in such variability will contribute to our knowledge of the factors underlying disease epidemics. Furthermore, knowledge of the transmission and dispersal of Gyrodactylus species in space and time within the host community is essential for a proper understanding of the etiology of gyrodactylosis and ultimately for the best management practices for the Atlantic salmon against $G$. salaris. Much relevant literature on the host specificity and transmission of gyrodactylids is found in unpublished theses, research reports and foreign journals of restricted accessibility. Nevertheless, here we attempt to review and identify processes which may be important in the transmission of $G$. salaris between components of the natural ecosystem.

\section{HOST SPECIFICITY OF GYRODACTYLIDS}

Most parasites infect a range of host species which form a continuum from those which are infected but cannot support the parasite, through those on which some reproduction is possible, to hosts on which reproductive output is maximised (Holmes 1979). For gyrodactylids, even hosts which cannot support the parasite may transport it, facilitating transfer to more suitable hosts (Bakke et al. 1991b). Unfortunately, accounts of gyrodactylid specificity often fail to consider this spectrum and deal only with host range. Furthermore, many descriptions implicitly or explicitly utilise host identity as a character for specific diagnosis (Ergens 1965. Prudhoe $\&$ Bray 1982), which may overestimate the diversity and underestimate the host range of gyrodactylids. These problems, and the taxonomic complexity of the genus, make it difficult to analyse patterns of specificity. For example, Cone \& Dechtiar (1986) showed that Gyrodactylus katharineri Malmberg, 1964, a parasite of Cyprinus carpio L., and G. mizellei Kritskyet Leiby, 1971, a Eurasian parasite of percid fishes in North America, are morphologically indistinguishable, despite the divergence in host and geographical distribution. Detailed laboratory study is needed for each species to determine the pattern of host utilisation. However, crowding of hosts in aquaria can break down barriers to cross-infections, allowing gyrodactylids to infect atypical hosts (Hargis 1953, Putz \& Hoffman 1963, Malmberg
Table 1. Gyrodactylus spp. Number of hosts infected by Gyrodactylus species, derived from survey data. (A) Based upon total data set of 319 species descriptions, excluding obvious synonyms and misidentifications; (B) based upon 76 species which have featured in more than 1 faunistic survey or have been used in experimental work

\begin{tabular}{|lrrrrr|}
\hline $\begin{array}{l}\text { No. of species } \\
\text { descriptions }\end{array}$ & 1 & 2 & 3 & 4 & $>4$ \\
\hline (A) 319 & 235 & 48 & 19 & 4 & 13 \\
(B) 76 & 23 & 27 & 13 & 4 & 9 \\
\hline
\end{tabular}

1970, 1972, 1973, Malmberg \& Malmberg 1970, Ergens 1983a). To date such detailed analysis has only been applied to $G$. salaris.

Although Bychowsky (1957) considered gyrodactylids the least specific of monogeneans, subsequent authors (e.g. Malmberg 1970) have regarded them as narrowly host-specific. This is superficially confirmed by published host records; after eliminating obvious synonymies and misidentifications, $74 \%$ of the 319 valid Gyrodactylus spp. are recorded from a single host species (Table 1A). However, by restricting analysis to those gyrodactylids which have featured in 2 or more field studies, or have been used experimentally, the proportion declines to $30 \%$ of 76 species (Table $1 B)$. This suggests that gyrodactylids are less hostspecific than commonly thought, and that narrow specificity is an artifact based on numerous species descriptions of gyrodactylids collected from only a single host. The prominent difference in susceptibility/ resistance between stocks of the same fish species (see Fig. 1) (Bakke et al. 1990b) and between individuals of the same stock (see Fig. 2) (Bakke et al. 1991a) examined experimentally further stresses the uncertainty in estimating host utilisation of gyrodactylids based on few observations.

Many gyrodactylids have been recorded on single occasions from hosts other than those normally infected; these transient infections are probably a result of inter-specific contact between fishes. An example is Gyrodactylus errabundus Malmberg, 1970 which could invade many other species from the true host Zoarces viviparus (L.) but could not live or feed on them (Malmberg 1970). Some gyrodactylids, however. exploit a range of fish species, reproducing on each. For example G. macrochiri Hoffman \& Putz, 1964 is reported from 8 species and 3 genera of centrarchid fishes (Hoffman \& Putz 1964, Hanek \& Fernando 1971. Rawson \& Rogers 1973, Barnhardt et al. 1976, Nicola \& Cone 1987). It infects different hosts in different localities and it is not clear which is the principal host. The species $G$. macrochiri reported by Hanek \& Fernando (1971) is an additional difficulty, suspected by Nicola \& Cone (1987) to be misidentified 
Four salmonid gyrodactylids, Gyrodactylus salaris, $G$. salmonis Yin et Sproston, 1948, G. colemanensis Mizelle et Kritsky, 1967 and G. derjavini Mikailov, 1975, are reported from more than 4 hosts. $G$. salaris has a particularly broad range, as shown in Tables $2 \& 3$. This broad specificity for attachment and reproduction does not appear to be present amongst the gyrodactylids of other fish groups; for example, the majority of Gyrodactylus species infect cyprinids and yet only 1 infects more than 4 hosts. The pattern of specificity of $G$. salaris cannot be related to the evolutionary relationships of the hosts, as Salmo trutta L. is less susceptible than e.g. Salvelinus fontinalis (Mitchell), S. alpinus (L.), Thymallus thymallus (L.) or Oncorhynchus mykiss (Walbaum) in laboratory experiments (see Fig. 3) (Tanum 1983, Malmberg 1988, Bakke \& Jansen 1991a, b, Bakke et al. 1991a). The host range of $G$. salaris outside the Salmonidae needs further investigation but the parasite does not appear to infect cyprinids IPhoxinus phoxinus (L.) and Rutilus rutilus (L.)], percids (Perca fluviatilis L.) or the lamprey Lampetra planeri (Bloch) (see Bakke \& Sharp 1990, Bakke et al. 1990a), and it can infect and survive for up to $8 \mathrm{~d}$ but not feed upon the eel Anguilla anguilla (Bakke et al. 1991c). Malmberg (1987b) thought that $G$. salaris was most closely related to $G$. thymalli Zitnan, 1960, which infects another riverine salmonid, the grayling $T$. thymallus. Our preliminary experiments indicate that $G$. salaris can reproduce on $T$. thymallus (see Bakke \& Jansen 1991 b), and further work will examine the host range of G. thymalli (see Lux 1990, Malmberg \& Malmberg 1991).

\section{ETHOLOGICAL AND PHYSIOLOGICAL MECHANISMS OF HOST SPECIFICITY}

We have found by a scrutiny of earlier observations that certain Gyrodactylus species vary from narrowly specific species which can utilise only a single host to those which can successfully attach for dispersal or establish and reproduce on several host genera. This includes G. pungitii Malmberg, 1964 (several host species during the colder periods of the year when fishes shoal), G. pharyngicus Malmberg, 1964 (2 host species), G. arcuatus (a number of temporary hosts) and G. errabundus Malmberg, 1970 (a pronounced ability to spread from its normal host to other fish species) (all according to Malmberg 1970); G. unicopula Gluchowa, 1955 (4 host species, according to MacKenzie 1970); G. gasterostei Gläser, 1974 (6 possible hosts, especially during the fish breeding season, according to Gläser 1974); G. katharineri (occurs on several fish genera, termed temporary substratum, especially at higher populations levels, according to Ergens 1983a); G. colemanensis (4 host species in the genera Salmo and
Salvelinus, according to Cone et al. 1983); G. salmonis (6 host species in the genera Salmo, Salvelinus and Oncorhynchus, according to Cone et al. 1983, Cone \& Cusack 1988); G. avalonia Hanek \& Threlfall, 1960 and

Table 2. Gyrodactylus salaris Malmberg, 1957. Review of records on freshwater fish in the Western Palaearctic. N: in nature; $\mathrm{H}$ : present in hatcheries or used in experiments

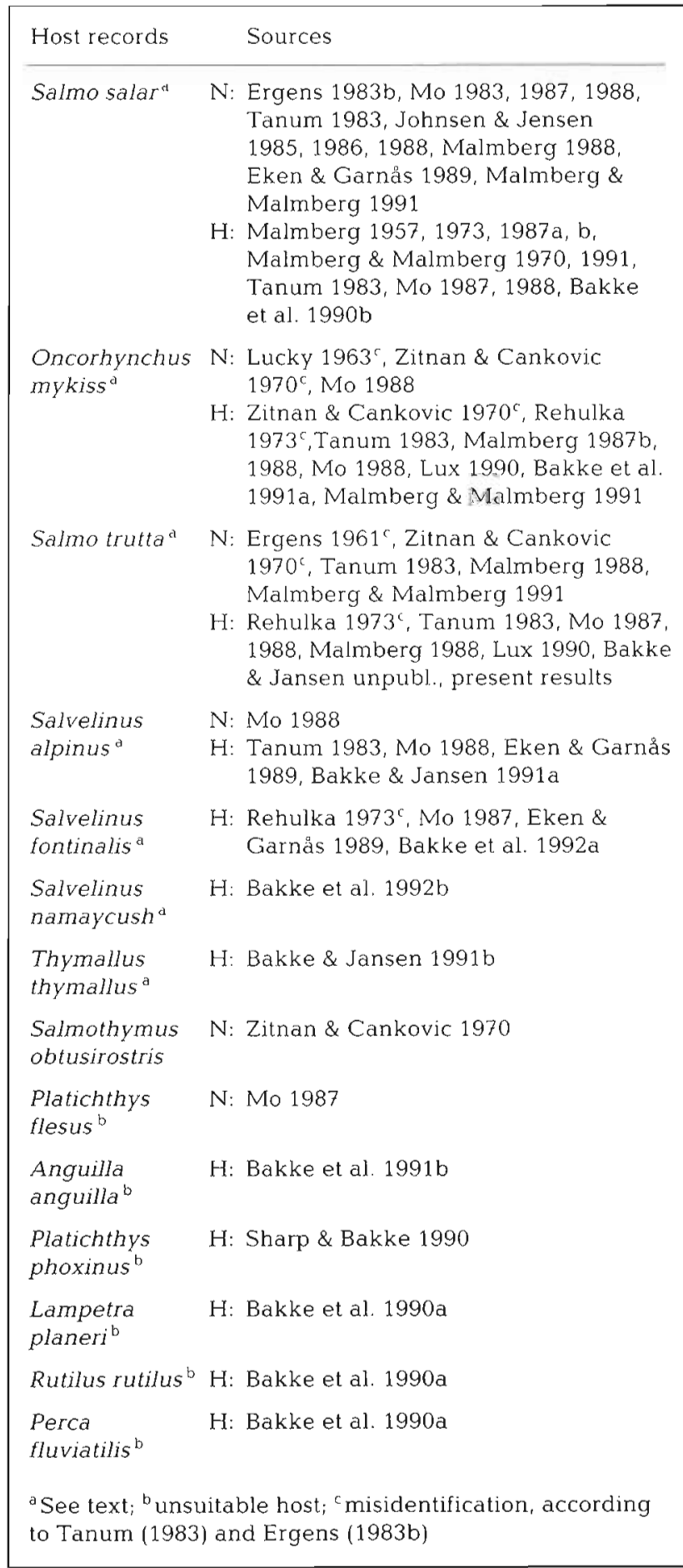


Table 3. Gyrodactylus spp. Review of gyrodactylid species (bold) associated with salmonids in the Western Palaearctic. $\mathrm{N}$ : in nature; $\mathrm{H}$ : present in hatcheries or used in experiments

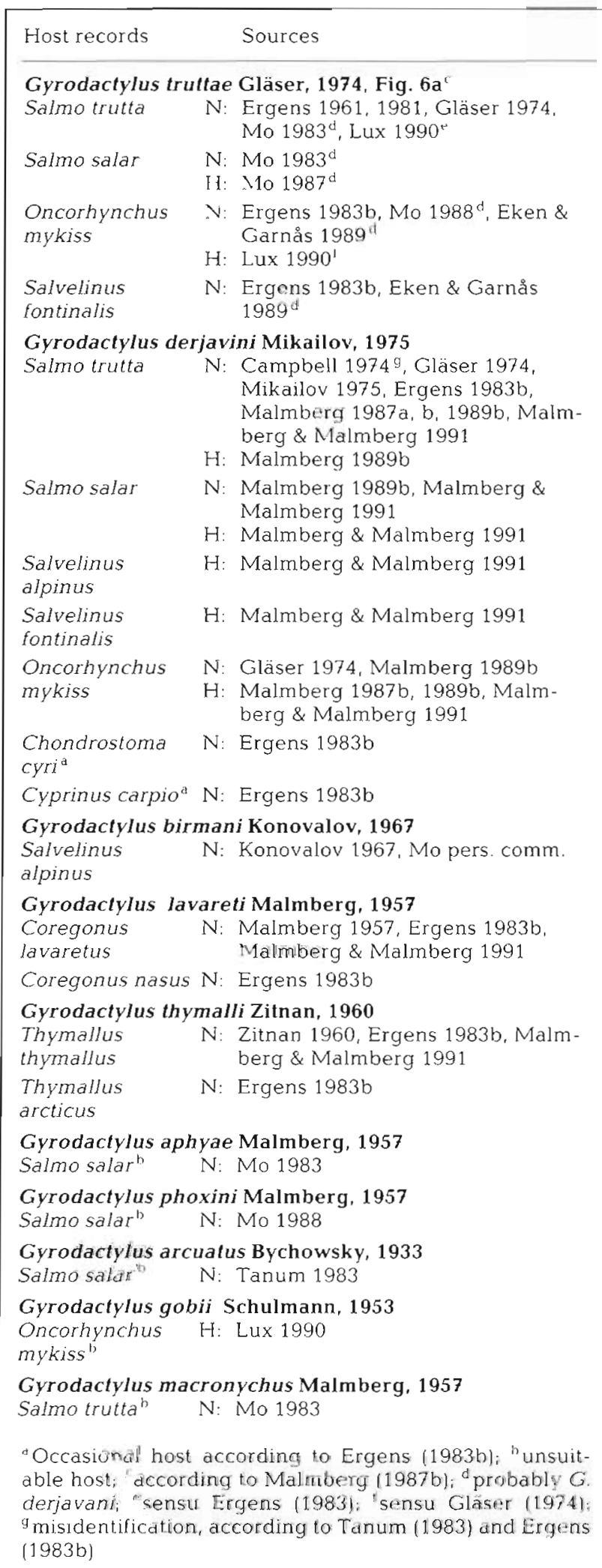

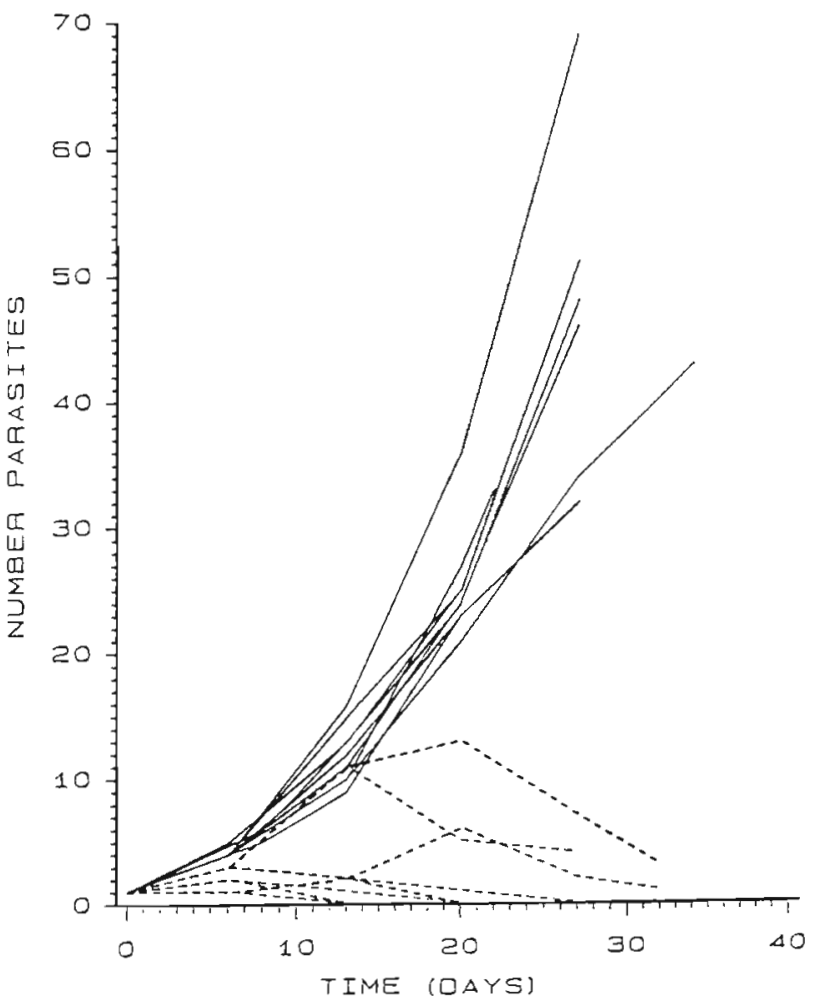

Fig. 1. Gyrodactylus salaris, Salmo salaris. Influence of intraspecific stock differences in salmonids for infrapopulation growth of $G$. salaris. Hosts: individually isolated Allantic salmon. Temperature: ca $12^{\circ} \mathrm{C}$ infection started with 1 gravid parasite; dashed lines: Baltic Neva stock $(n=10)_{i}$ continuous lines: Norwegian Lone stock $(n=10)$. (After Bakke et al. 1990b)

G. canadensis Hanek \& Threlfall, 1969 (show only a weak specificity for salmonid fishes, according to Cone \& Wiles 1985); G. stellatus Crane \& Mizelle, 1967 (3 host species, of different genera, according to Kamiso \& Olson 1986); G. bullatarudis Turnbull, 1956 (found on distinctly related hosts, according to Harris 1986); and G. goerani Hanek \& Fernando, 1971 (4 host species, according to Nicola \& Cone 1987). According to the results of Wood \& Mizelle (1957), $22 \%$ of a total of 28 Gyrodactylus spp. may occur on more than 1 host species and based on the data of 33 Gyrodactylus spp. listed by Margolis \& Arthur (1979), $58 \%$ could be characterized as being host specific, $39 \%$ as narrow in host specificity and $3 \%$ as having a broad host specificity. At least 3 mechanisms maintain these patterns.

Firstly, behavioural mechanisms may maintain the parasite on the normal host. For example Gyrodactylus gasterostei Gläser, 1974 transmits freely to uninfected Gasterosteus aculeatus (L.), up to $10^{\prime}$ ". per day transferring in laboratory experiments (Harris 1982, section 4.1). Under identical conditions, transmission 


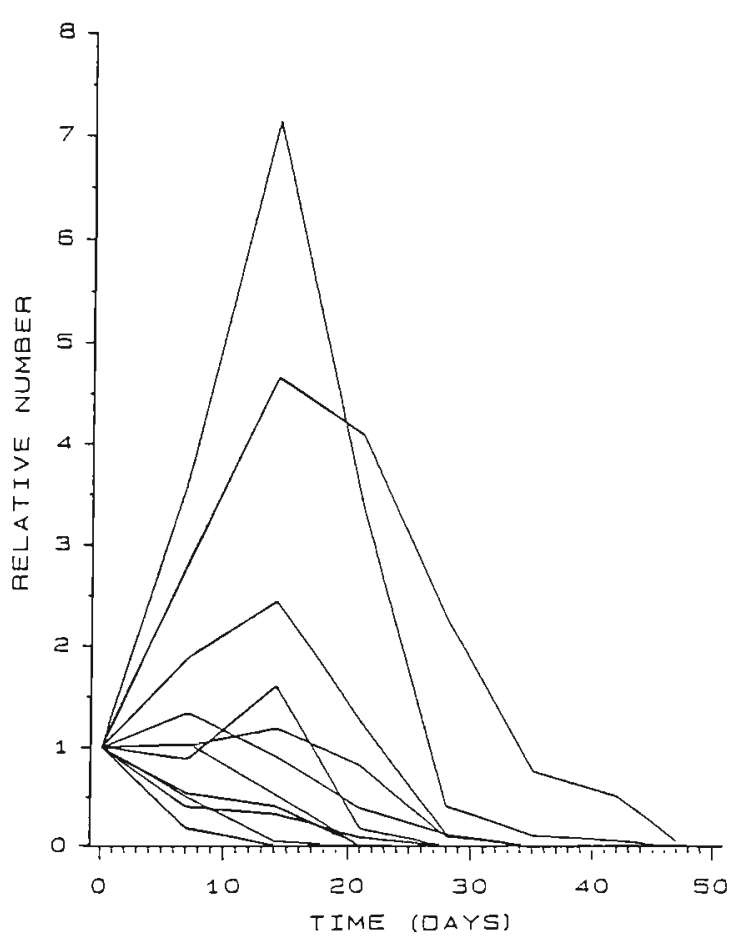

Fig. 2. Gyrodactylus salaris, Oncorhynchus mykiss. Influence of intraspecific differences within 1 salmonid host stock for infrapopulation growth of $G$. salaris. Hosts: individually $(\mathrm{n}=11)$ isolated rainbow trout. Temperature: 12 to $13^{\circ} \mathrm{C}$; relative number: no. of parasites in relation to start infection at time 0 . (After Bakke et al. 1991a)

to Pungitius pungitius (L.) and Phoxinus phoxinus was, however, only $1 \%$. Gyrodactylus salaris also shows a similar mechanism reducing the probability of attachment to Phoxinus phoxinus, Rutilus rutilus and Perca fluviatilis in relation to salmon (see Bakke \& Sharp 1990, Bakke et al. 1990a), and also to bottom dwellers as the eel and lamprey. However, for such fish species with frequent bottom contact, the differences are less prominent (Bakke \& Sharp 1990, Bakke et al. 1991b, authors' unpubl. data). Gyrodactylus salaris, detached or attached to a dead host, seems to change its behaviour. The characteristic 'searching activity' after a new host and transmission rate increases and the selective host-preference decreases. This seems to be a dispersal strategy as it increases the chance of incorporation of transport hosts (Harris 1980, Bakke et al. 1991b, authors' unpubl. data). Nevertheless, there seem to be mechanisms not linked to host behaviour, which generally prevent transfer to innapropriate hosts for reproduction and may allow narrowly specific gyrodactylids to coexist without competition (Harris 1985). The specific mechanisms and behavioural triggers involved in such transmission, both for attached and detached parasites of different ontogenetical life cycle stages, are unknown for gyrodactylids.

A second physiological mechanism may limit Gyrodactylus salaris infections on eels. $G$. salaris infects this host more readily than it does Phoxinus phoxinus, Rutilus rutilus, Perca fluviatilis or Lampetra planeri, and persists for longer, but parasites cannot reproduce, and die after some days (Bakke \& Sharp 1990, Bakke et al. 1990a, Bakke et al. 1991b). The short duration of infection (ca 8 d at $13{ }^{\circ} \mathrm{C}$ ) compared to the normally longer lifespan of $G$. salaris at this temperature (see Jansen \& Bakke 1991) suggests that the parasite is unable to feed on the eel. G. salaris attached to the skin of this host although Buchmann (1988) has pointed out that no monogenean successfully infects eel skin, while several species infect the gills. This suggests the presence of a non-specific mechanism, either mechanical barriers to feeding, such as the thickness of the mucus layer (Jakubowski 1960), or inhibitory or toxic component of eel skin or mucus, which could affect $G$. salaris in several ways, e.g. through inhibition of enzymes secreted from the pharyngeal glands and used for extracorporeal feeding.

The third mechanism maintaining specificity has only been noted in Gyrodactylus salaris infecting salmonids. The parasite appears to transmit to almost all salmonids tested (see Bakke 1991), although the species, stocks and individuals differ in their responses to the parasite. In experiments with Norwegian stocks of Salmo salar the parasite population generally increased without check until the hosts died. On a Baltic stock of this fish, however, and on e.g. Oncorhynchus mykiss (see Bakke et al. 1991a) and Salvelinus fontinalis (see Bakke et al. 1992a), parasite populations were limited on initially susceptible host individuals by a host response 8 to $20 \mathrm{~d}$ after infection (Fig. 1). Even amongst individual rainbow trout considerable heterogeneity of innate resistance and response is observed (Fig. 2), although all specimens eventually mobilised an effective immune response (Bakke et al. 1991a; while on Salmo trutta, Coregonus lavaretus (L.) and Salvelinus namaycush (Walbaum) the parasite population failed to grow significantly (Fig. 3) (Bakke et al. 1992b, authors' unpubl. data), although attachment occurred, but in these cases apparently at a reduced rate (see Bakke 1991). Variation is also seen, from highly susceptible to resistant, amongst the full sib progeny of arctic char Salvelinus alpinus (see Bakke \& Jansen 1991a), which was found, however, not to influence the attachment rate (Bakke, Jansen \& Sterud unpubl.). These differences in innate resistance and timing and efficacy of the host reaction are probably genetic, as has been shown in the case of the host response of guppies to G. bullatarudis (see Madhavi \& Anderson 1985, Jansen et al. 1991). 


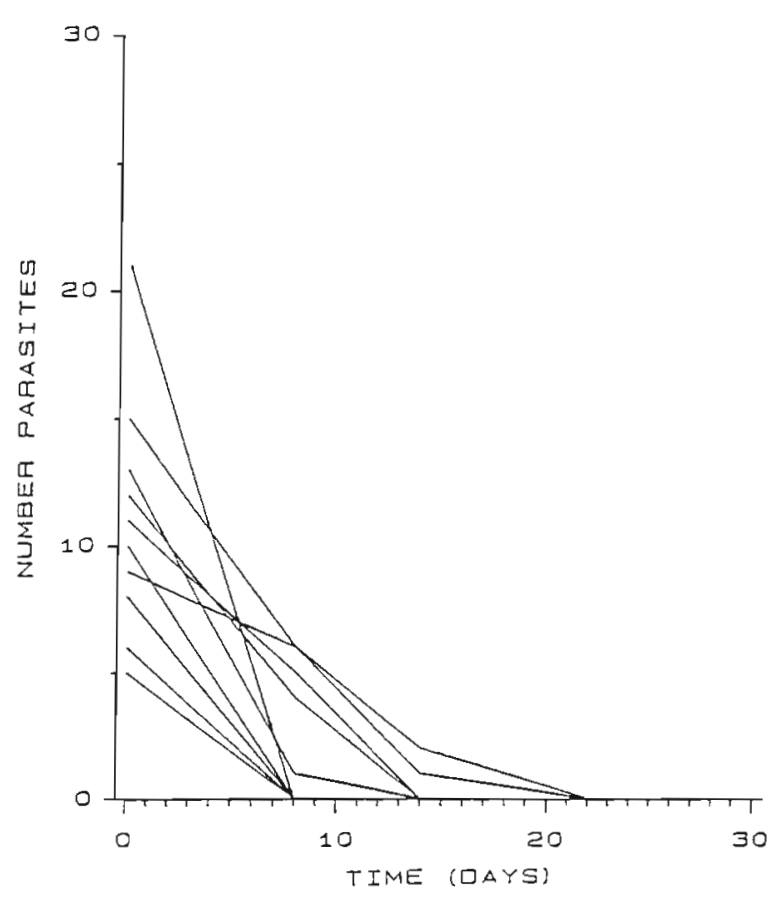

Fig. 3. Gyrodactylus salaris, Salmo trutta. Influence of a resistant salmonid host stock on the infrapopulation growth of G. salaris. Hosts: individually $(n=10)$ isolated brown trout Temperature: ca $12^{\circ} \mathrm{C}$. (Original results)

\section{TRANSMISSION}

Gyrodactylids cannot swim and are transmitted by 4 routes: (1) direct transfer during contacts between fishes; (2) contact between fishes and detached parasites on the substrate (3) contact between fishes and detached parasites in the drift; (4) contact between living fishes and infected dead fishes.

\section{Direct transier}

Gyrodactylid transmission is reduced when infected and uninfected hosts are separated by a barrier through which the parasites can pass (Parker 1965, Malmberg 1970. Harris 1982), demonstrating the importance of host contact for transmission. Bychowsky (1957) felt this to be the most important route for transmission and Kamiso \& Olson (1986) found that Gyrodactylus stellatus transferred most efficiently when there was unrestricted contact between fishes. Although host-host contact accounts for a large proportion of transmission, nevertheless a small proportion of parasites do succeed in transferring in the presence of a barrier, presumably by crawling through the mesh and then being picked up by the fish from the substrate. Harris (1982) estimated that up to $10 \%$ of transmission could occur by this indirect route in $G$. gasterostei.

Host-host contact must be most important for gyrodactylids of pelagic hosts as dead hosts and detached parasites would rapidly be swept out of contact with living hosts. Llewellyn (1984) studied transmission of Isancistrum subulatae, a gyrodactylid infecting the pelagic squid Alloteuthis subulata, and demonstrated that transmission occurred when squid made contact with arms cut from infected squid. As the host never rests on the sea floor, and avoids contact with other squid, transmission probably occurs during agonistic behaviour or copulation, a hypothesis supported by the observation that prevalence increases in larger, sexually mature squid (Llewellyn 1984).

\section{Transmission by detached parasites}

This route is probably most important for gyrodactylids of benthic hosts which have opportunities for contact with the substrate. Detached gyrodactylids readily attach to, and can move over, wet glass and plastic surfaces, making infections from landing nets which have previously contained infected hosts a possibility (Mo 1987).

Gyrodactylus macrochiri achieved higher infections when wire cages containing the hosts were placed in contact with the substrate rather than suspended in the water column (Hoffman \& Putz 1964, see also Parker 1965), implying that transmission by detached parasites was occurring, although it is possible that host behaviour differed in the 2 experiments, affecting parasite transmission. Detached free-living $G$. salaris have been found in the outlet filters of infected salmon hatcheries in Norway and Mo (1987) found large numbers of $G$. salaris on the bottom of aquaria which had contained infected salmon for 20 h. Parker (1965), Harris (1982), Eken \& Garnås (1989) and Bakke et al. (1991b, authors unpubl. data) also report transmission of detached gyrodactylids.

Gyrodactylids may become detached from their hosts through accident, active migration or as a result of a host response (Lester 1972, Scott \& Anderson 1984). Because detached parasites are not killed but are able to reinfect the same or a different host, the host response does not necessarily stabilize the parasite population behaviour (May \& Anderson 1978), and at high host densities sufficient flukes may reattach to significantly reduce the impact of the host response on the parasite suprapopulation. 


\section{Transmission by detached parasites in the drift}

The ability of detached parasites within the planktonic drift to reinfect fishes may have been underestimated, at least under lotic conditions. Both Parker (1965) and Eken \& Garnås (1989) reported transmission of detached, drifting gyrodactylids to fishes. We have observed a mean parasite intensity of 6.6 Gyrodactylus salaris per fish in 35 previously uninfected salmon parr (Age $1+$ ) isolated in a cage in an infected river for $20 \mathrm{~d}$, indicating that several $\mathrm{G}$. salaris probably drifted into contact with the parr (Jansen \& Bakke unpubl.).

\section{Transmission from dead fishes}

When an infected fish dies the behaviour of its gyrodactylids changes. Although some species continue to feed (Kulemina 1979) others may abandon the host (Malmberg 1970) and their activity may increase (Harris 1980), increasing the chance of transmission to living fishes. Both transport and natural hosts were more heavily infected with Gyrodactylus salaris when exposed to dead salmon than when exposed to a living host (Bakke et al. 1991b), indicating the possible importance of dead fishes in gyrodactylid transmission. Scott \& Anderson (1984) also found transmission from dead fishes as even more important than from living hosts in their studies of $G$. bullatarudis on guppies, possibly because dead fishes attract the attention of living guppies (Scott 1982). Although transmission from dead fishes is clearly efficient, the importance of this route in gyrodactylid epidemiology is limited by parasite survival after host death and by the speed at which parasites leave a dead fish. Up to $50 \%$ of $G$. gasterostei left the dead host within $18 \mathrm{~h}$ at $15^{\circ} \mathrm{C}$ (Harris 1980), and their subsequent chance of transmission, without the focus of the fish carcass to attract other potential hosts, is presumably the same as that for detached parasites. The importance of dead fishes is also limited by the number of infected hosts dying. In many gyrodactylid-host interactions this number is probably very small, but Scott \& Anderson (1984) found parasite-induced host mortality to be important for parasite dispersion in $G$. bullatarudis. The same might be expected in Norwegian river systems for $G$. salaris, which generally is reported to grow exponentially until host death (Johnsen \& Jensen 1986, 1991). In fact, the high abundance of $G$. salaris reported by Heggberget \& Johnsen (1982) at low salmon densities due to parasite-induced fish mortality may be explained by such mechanisms, as the salmon parr also rest and have frequent contact with the bottom substrate.

\section{Transmission between host species}

Gyrodactylids lack a specific transmission stage and as the mobility of detached parasites is limited, intraspecific transmission relies on host aggregation and contact during shoaling, agonistic or reproductive encounters. However, opportunities for interspecific transfer are more restricted. Gläser (1974) noted the importance of multispecies shoals of fishes for inter-specific transmission, and predator-prey and scavenger-dead fish interactions may also be important routes. Predator-prey interactions may have been important in the speciation of gyrodactylids, as predators are often infected with gyrodactylids closely related to those infecting their prey. For example the Gyrodactylus wageneri species complex (see Malmberg 1970) are principally found on cyprinids, but related species are found on predators sharing the same habitat. Furthermore, gyrodactylids from prey species are occasionally found on predators. Malmberg (1974) recorded a species normally found on cottids on Salmo trutta, and G. macronychus Malmberg, 1957 as well as G. aphyae Malmberg, 1957 and G. phoxini Malmberg, 1957, 2 species normally restricted to the minnow Phoxinus phoxinus, have been found on salmonids in the same river system (Mo 1983, 1988, Tanum 1983). G. arcuatus Bychowsky, 1933, a species which normally infects the stickleback Gasterosteus aculeatus, has also been found on salmon (Tanum 1983). In Nearctic freshwaters, $G$. brevis Crane et Mizelle, 1967, normally a parasite of a cyprinid (Hesperoleucas navarroensis), was originally described by Crane \& Mizelle (1967) from the predatory trout Salmo gairdneri (= Oncorhynchus mykiss) (see Cone et al. 1983) This process may also occur in reverse. Scavenging on dead fishes may also form an important route of interspecific transmission, and the record of $G$. salaris from flatfish may be an example of this (see Mo 1987; Table 2).

\section{Parasite behaviour and transmission}

Although gyrodactylid transmission has generally been regarded as a function of host behaviour only, parasite behaviour may also be very important, at least during host-host contact. Gyrodactylids inhabiting the gill chamber and other cryptic sites (e.g. Gyrodactylus cryptarum Malmberg, 1970 in the acoustico-lateralis canals) must presumably migrate onto the surface of the fish skin before transmission can occur during hosthost contact. Even the action of the host response may involve a component of modified parasite behaviour when the gyrodactylids become detached from the host. For example Gyrdicotylus gallieni Vercammen- 
Grandjean, 1960 lives in the mouth of Xenopus laevis and accidental dislodgement would result in swallowing. The age structure of the parasite population suggests that this occurs rarely. However, Harris \& Tinsley (1987) noted the synchronous appearance of living $G$. gallieni outside of the hosts 1 to 2 mo after infection, implying a migration of parasites out of the mouth, possibly for the purpose of transmission. Srivastava \& James (1967) recorded Gyrodactylus medius Kathariner, sensu Srivastava et James, 1967, normally a gill parasite of the rockling Onos mustela, as occurring on the skin in heavy infections, which may also suggest migration by the parasite, and Cone \& Cusack (1989) describe migrations of Gyrodactylus colemanensis on the host skin after infection. Finally Harris $(1986,1988 b, 1989)$ recorded complex changes in parasite distribution and crowding during infections of Gyrodactylus turnbulli Harris, 1986 on guppies, which were probably due to migrations upon the host.

The parasites can discriminate between host species during transmission (Harris 1982, Bakke \& Sharp 1990, Bakke et al. 1991b), probably using multiciliate 'spike' sensilla (Lyons 1969a, b) found only in gyrodactylids (Harris 1983) and which may be chemosensory (Lyons 1969b). Chemoreception forms an important part of monogenean transmission biology (Lyons 1969b, Llewellyn 1984) allowing gyrodactylids to recognise suitable hosts before transfer (Cone \& Cusack 1989). Small diffusible molecules (e.g. urea) activate the swimming larvae of oviparous monogeneans (Kearn 1967, 1986), but are too generally distributed to allow host discrimination. However, the chemical composition of fish skin appears to be species-specific (Barry \& O'Rourke 1959, O'Rourke 1961, Lubbock 1979) and contains sufficient chemical information to allow recognition of individuals by conspecifics (Bardach \& Todd 1970). It could therefore produce chemoattractive cues suitable for use by the gyrodactylids.

\section{TRANSMISSION, HOST SPECIFICITY AND THE EPIDEMIOLOGY OF GYRODACTYLUS SALARIS INFECTIONS}

In Norway, Gyrodactylus salaris was first noted as a pathogen of Salmo salar during the mid-1970's (Johnsen 1978) and was thought to be an opportunist infecting already weakened fishes. Subsequently the parasite was thought to have been introduced with Baltic salmon stocks (Johnsen \& Jensen 1986, Malmberg 1988). This origin for the parasite is disputed (Halvorsen \& Hartvigsen 1989), although supported by differences in susceptibility between Baltic and Norwegian salmon (Bakke et al. 1990b, see Johnsen \& Jensen 1991). The ecology of the Atlantic salmon has been extensively modified by man, with largescale changes in salmon population density and genetic structure (Anonymous 1990). As gyrodactylid population dynamics probably are unstable (May \& Anderson 1978, Scott \& Anderson 1984), host density and genetics may have a major effect on parasite population behaviour $i$ it is therefore necessary to consider human influences on the host in relation to parasite translocation, transmission and parasite population growth. $G$. salaris can coexist on wild, restocked and farmed salmonids in the same watershed (Eken \& Garnås 1989) and transmission between these hosts must be considered in assessing the epidemiology of the disease.

Gyrodactylus salaris principally affects salmon parr of $\mathrm{O}^{+}$to $3 \mathrm{yr}$ in age. In suitable areas of river these fishes form large populations, within which individuals may be territorial (Kalleberg 1958, Saunders \& Gee 1964, Symons 1976). Individuals do not move far from their territories (Saunders \& Gee 1964) but intraspecific agonistic interactions would provide opportunities for host-host transmission of $G$. salaris during physical contact when nipping. However, most interactions between territorial parr would involve threat display rather than contact (J. Heggenes pers. comm.), indicating the importance of indirect transmission in the Salmo salar-Gyrodactylus salaris associations. In Norway during spring and summer, these infections increase, but in winter, when water temperature in Norwegian rivers are close to $0^{\circ} \mathrm{C}$ and fish activity is reduced to a minimum, parasite populations decline although the parasite still can reproduce at this temperature (Jansen \& Bakke 1991a).

The spatial and temporal patterns of parasite dispersal between populations and age-classes of salmon parr are uncertain. Adult salmon re-entering freshwater are initially uninfected but contract Gyrodactylus salaris as they swim through populations of infected parr. Infections may be contracted from detached parasites adhering to gravel and weeds in areas where epidemics on parr are occurring; alternatively, infected precocious males may transmit the parasite to adults during spawning (see Malmberg \& Malmberg 1991). Adults swim rapidly and can cover 30 $\mathrm{km}$ in $2 \mathrm{~d}$ (L. P. Hansen unpubl.), so the potential of these fishes to spread infection is considerable. Smolts passing through populations of parr on their way to the sea, are probably similarly important (Malmberg \& Malmberg 1991). Pure transport hosts may also spread G. salaris between populations of parr within watersheds. Eels can sustain infections for several days (Bakke et al. 1991b) and could therefore transport the parasite considerable distances. This is probably also valid for $G$. salaris infections of the flounder Platichthys flesus (see Mo 1987). In these ways G. salaris, which 
Fig. 4. Gyrodactylus salaris, Salmo salar. Circulation of $G$. salaris within the host community. Thick lines: life cycle of anadromous Atlantic salmon; thin lines: possible routes of circulation of G. salaris within the salmon river ecosystem. Epidemiological data on relative importance of the different salmon cohorts and routes, and seasonal dynamics of the system under natural conditions are generally lacking

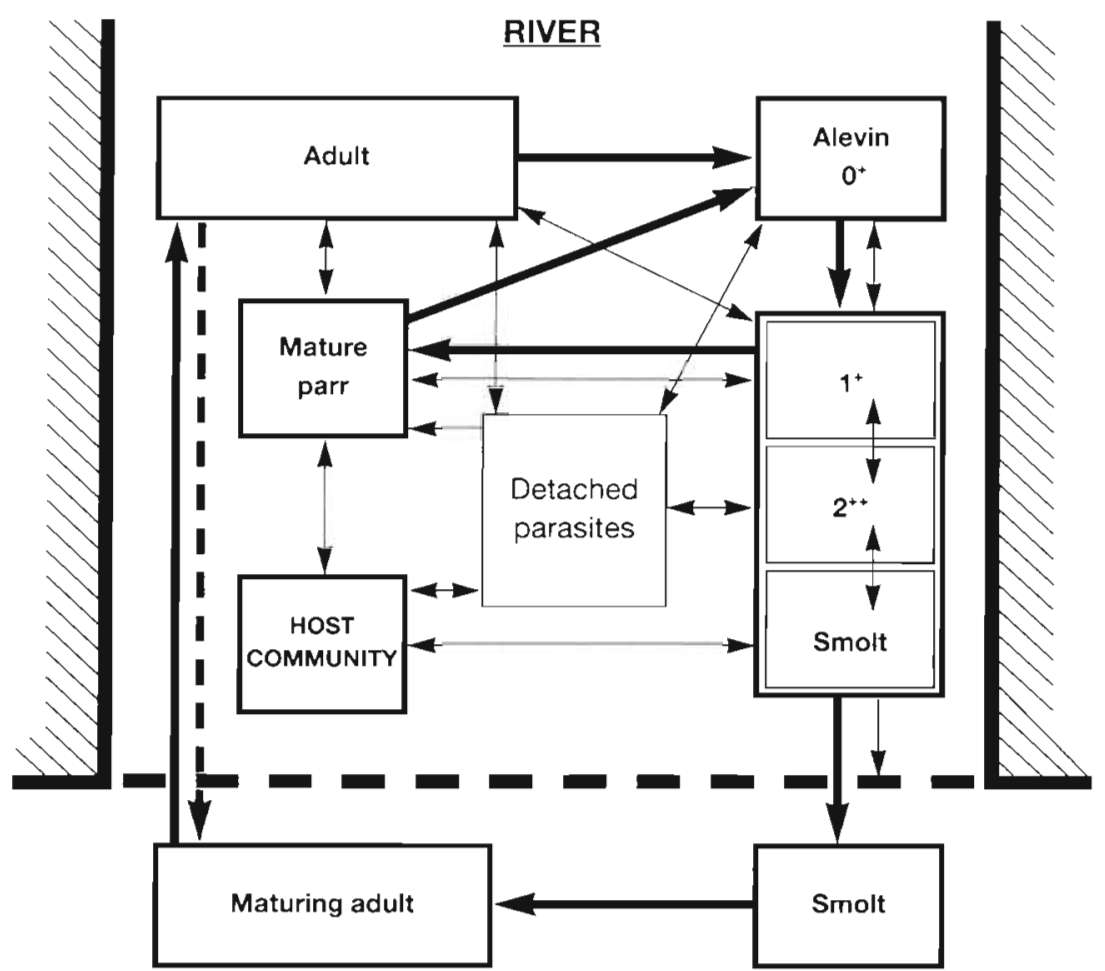

SEA cannot survive in sea water, may be also transferred between rivers through regions of brackish water, as they can endure up to $7.5 \%$ salt water for weeks (Soleng \& Bakke 1991).

Possible transmission patterns of Gyrodactylus salaris within and between populations of salmon parr are summarised in Fig. 4. Rapid transmission within shoals of the new generation of parr in the spring, and the dissemination between parr populations of parasites by adult salmon, smolts and possibly eels and flounders, appear to be the most important features in Norway. The importance of other transmission routes remains unclear. We have no evidence of infection of salmon eggs, only evidence for infections of alevins, but the pathogenicity of $G$. salaris at this stage, and the importance of this age group as hosts of the parasite, are unknown. In order to understand the epidemiology of $G$. salaris, and to develop rational control strategies, the relative importance of all of these cohorts and possible routes of transmission will need to be investigated.

Acknowledgements. We appreciate the comments on the salmonid infection records in Western Palaearctic given by Tor A. Mo, Veterinary Institute, Oslo. This study was supported by a grant from the Directorate for Nature Management, Trondheim.

\section{LITERATURE CITED}

Anderson, R. M., May, R. M (1978). Regulation and stability of host-parasite population interactions. I. Regulatory processes. J. Animal. Ecol. 47: 219-247

Anonymous (1990). Report on the Norwegian meeting on impacts of aquaculture on wild stocks. North Atlantic Salmon Conservation Organization, Council Paper 28: 1-9

Bakke, T. A. (1991). A review of the inter- and intraspecific variability in salmonid hosts to laboratory infections with Gyrodactylus salaris Malmberg. Aquaculture 98: 303-310

Bakke, T. A., Jansen, P. A. (1991a). Susceptibility of arctic char (Salvelinus alpinus) to Gyrodactylus salaris Malmberg (Monogenea). Bull. Scand. Soc. Par. 1:60

Bakke, T A., Jansen, P. A. (1991b). Susceptibility of grayling (Thymallus thymallus) to Gyrodactylus salaris Malmberg (Monogenea). Bull Scand. Soc. Par. 1. 61

Bakke, T. A., Jansen, P. A., Brabrand, Å. (1990a). Susceptibility and resistance of brook lamprey, Lampetra planeri (Bloch), roach, Rutilus rutilus (L.) and perch, Perca fluviatilis L. to Gyrodactylus salaris Malmberg (Monogenea). Fauna norv. (Ser. A) 11:23-26

Bakke, T. A., Jansen, P. A., Hansen, L. P. (1990b). Differences in the host resistance of Atlantic salmon (Salmo salar) stocks to the monogenean Gyrodactylus salaris Malmberg, 1957. J. Fish Biol. 37: 577-587

Bakke, T. A., Harris, P. D., Jansen, P. A. (1992a). The susceptibility of Salvelinus fontinalis (Mitchell) of Gyrodactylus salaris Malmberg (Platyhelminthes; Monogenea) under experimental conditions. J. Fish Biol. (in press)

Bakke, T. A., Jansen, P. A., Grande, M. (1992b). The susceptibility of Salvelinus namaycush (Walbaum) to Gyrodactylus salaris Malmberg (Platyhelminthes; Monogenea) under 
experimental conditions. Fauna norv. (Ser. A) 12: (in press) Bakke, T A., Jansen, P. A., Kennedy, C. R. (1991a). The host specificity of Gyrodactylus salaris Malmberg (Platyhelminthes, Monogenea): susceptibility of Oncorhynchus mykiss (Walbaum) under experimental conditions. J. Fish Biol. 39: 45-57

Bakke, T. A., Jansen, P. A., Hansen, L. P. (1991 b). Experimental transmission of Gyrodactylus salaris Malmberg (Platyhelminthes, Monogenea) from the Atlantic salmon (Salmo salar) to the European eel (Anguilla anguilla). Can. J. Zool. 69: 733-737

Bakke, T. A., Sharp. L. A. (1990). Susceptibility and resistance of minnows, Phoxinus phoxinus (L.) to Gyrodactylus salaris Malmberg, 1957 (Monogenea) under laboratory conditions. Fauna norv. (Ser. A) 11:51-55

Bardach, J. E., Todd, J. H. (1970). Chemical communication in fishes. In: Johnston, J. W., Moultron. D. C., Turk, A. (eds.) Advances in chemoreception, Vol. 1. Meredith Corp., New York

Barnhardt, M. C., Calderwood, G. W., Powell, E. C. (1976) Helminth parasites of some lowa fishes. Proc. lowa Acad Sci. 83 (2): $64-66$

Barry, J. M., O'Rourke, F. J. (1959). Species specificity of fish mucus. Nature, Lond. 184: 2039

Bauer, O. N. (1958). Parasitic diseases of cultured fishes and methods and their prevention and treatment. In: Dogiel V. A., Petrushevski, G. K., Polyanski, Yu, I. (eds.) Parasitology of fishes. Translated by Z. Kabata 1961. Oliver \& Boyd Ltd, Edinburgh, p. 267-300

Bauer, O. N. (1988). Epizootiological significance of monogeneans. In: Skarlato, $O$. A. (ed.) Investigations of monogeneans in the USSR, A. A. Balkema, Rotterdam, p. 137-142 (Russian translation series 62)

Buchmann, K. (1988). Pseudodactylogyrose i oppdrette ål. Licentiatafhandling, Inst. Vet. Microbiol. Hyg., Den Kgl. Vet.-Landbohøjskole, København 1988. (In English, Danish summary\}

Bychowsky, B. E. (1957). Monogenetic trematodes. Their systematics and phylogeny. Akad. Nauk USSR. (English transl. by A.l.B.S., Washington, D. C. W. J. Hargis, Jr (ed.) 1961)

Campbell, A. D. (1974). The parasites of fish in Loch Leven. Proc. R. Soc. Edinb., Sec. B (Nat. Environ.) 74: 347-364

Cone, D. K., Beverly-Burton, M., Wiles, M., McDonald, T E. (1983). The taxonomy of Gyrodactylus (Monogenea) parasitizing certain salmonid fishes of North America, with a description of Gyrodactylus nerkaen. sp. Can. J. Zool. 61: $2587-2597$

Cone, D. K., Cusack, R. (1988). A study of Gyrodactylus colemanensis Mizelle and Kritsky, 1967 and Gyrodactylus salmonis (Yin and Sproston, 1948) (Monogenea) parasitizing captive salmonids in Nova Scotia. Can. J. Zool. 66: $409-415$

Cone, D. K., Cusack, R. (1989). Infrapopulation dispersal of Gyrodactylus colemanensis (Monogenea) on fry of Salmo gairdneri. J. Parasitol. 75: 702-706

Cone, D. K., Dechtiar, A. O. (1986). On Gyrodactylus katharineri Malmberg, 1964, G. lotae Gussev, 1953, and G. Iucii Kulakovskaya, 1952 from host fishes in North America. Can. J. Zool. 63: 956-960

Cone, D. K., Wiles, M. (1985). The systematics and zoogeography of Gyrodactylus species (Monogenea) parasitizing gasterosteld fishes in north America. Can. J Zool. 63: $956-960$

Crane, J. W. Mizelle, J. D. (1967). Studies on monogenetic trematodes. XXXI. Five new species of Gyrodactylus from California fishes. J. Parasitol. 53: 270-273
Dolmen, D. (1987). Gyrodactylus salaris (Monogenea) in Norway; infestations and management. In: Stenmark, A., Malmberg, G. (eds.) Parasites and diseases in natural waters and aquaculture in Nordic countries. Proceedings Zoo-Tax-Symposium, Stockholm 1986. Naturhistoriska Riksmuseet, Stockholm, p. 63-69

Eken, E., Garnås, E. (1989). Utbredelse og effekt av lakseparasitten Gyrodactylus salaris på Østlandet 1988. Fylkesmannen i Buskerud, Miljøvernavd., Rapport nr. 1: 1-35 (In Norwegian)

Ergens, R. (1961). Two further species of monogenetic trematodes of the genus Gyrodactylus Nordmann, 1832, from Czechoslovakia. Vestn. Cesk. Spol. Zool. 25: 25-27 (In German, Czechoslavakian summary)

Ergens, R. (1965). Die Morphogenese der Chitinoidenteile des Haptors bei Gyrodactylus decorus Malmberg, 1965 (Monogenoidea) und ihre Morphologisch-metrische Variabilität. Z. Parasitenkd. 25: 359-370

Ergens, R. (1981). Variability of hard parts of opisthaptor in Gyrodactylus trutta Gläser, 1974 (Gyrodactylidae: Monogenea). Folia Parasitol. (Prague) 28: 37-42

Ergens, R. (1983a). A survey of the results of studies on Gyrodactylus katharineri Malmberg, 1964 (Gyrodactylidae: Monogenea). Folia Parasit. (Prague) 30: 319-327

Ergens, R. (1983b). Gyrodactylus from Eurasian freshwater Salmonidae and Thymallidae. Folia Parasitol. (Prague) 30: $15-26$

Gläser, H.-J (1974). Sechs neue Arten der Gyrodactyluswageneri-Gruppe (Monogenea, Gyrodactylidae) nebst Bemerkungen zur Präparation, Determination, Terminologie und Wirtsspezifisität. Zool. Anz., Jena 192: 56-76

Halvorsen, O., Hartvigsen, R. (1989). A review of the biogeography and epidemiology of Gyrodactylus salaris. NINA Utredning 2: 1-14

Hanek, G., Fernando, C. H. (1971). Monogenetic trematodes from the Bay of Quinte area, Ontario, II. Genus Gyrodactylus Nordmann, 1832. Can. J. Zool. 49: 1331-1341

Hargis, W. J. Jr (1953). Monogenetic trematodes of Westhampton Lake fishes. III. Part. 2. A discussion of hostspecificity. Proc. helminth. Soc. Wash. 20: 98-104

Harris, P. D. (1980). The behaviour of Gyrodactylus on living hosts. Proceedings of the 3rd European Muiticolloqium of Parasitology, Cambridge 1980. Abstract of papers delivered at colloquia and seminars. p. 97

Harris, P. D. (1982). Studies of the Gyrodactyloidea (Monogenea). Ph.D thesis, University of London

Harris, P. D. (1983). The morphology and life-cycle of the oviparous Oogyrodactylus farlowellae gen. et sp. nov. (Monogenea, Gyrodactylidea). Parasitology 87: 405-420

Harris, P. D. (1985). Species of Gyrodactylus von Nordmann, 1932 (Monogenea: Gyrodactylidae) from freshwater fishes in southern. England, with a description of Gyrodactylus rogatensis sp. nov. from the bullhead Cottus gobio L. J. nat. Hist. 19: 791-809

Harris, P. D. (1986). Species of Gyrodactylus von Nordmann. 1932 (Monogenea Gyrodactylidae) from poecilid fishes, with a description of $G$. turnbullisp. nov. from the guppy, Poecilia reticulata Peters. J. nat. Hist. 20: 183-191

Harris, P. D. (1.988a). Is gyrodactylid intra-embryonic reproduction sexual or asexual? Evidence from Feulgen microdensitometry. Proceedings of the First Int. Conf. on Monogenea, Ceske Budejovice, 17 Institute of Parisitology of the Czechoslovak Academy of Sciences, Ceske Budejovice, Crechoslovakia

Harris, P. D. (1988b). Changes in the site specificity of Gyrodactylus turnbulli Harris, 1986 (Monogenea) during infections of individual guppies (Poecilia reticulata Peters 
1859). Can. J. Zool. 66: 2854-2857

Harris, P. D. (1989). Interactions between population growth and sexual reproduction in the viviparous monogenean Gyrodactylus turnbulli Harris, 1986 from the guppy Poecilia reticulata Peters. Parasitology 98: 245-251

Harris, P. D., Tinsley, R. C. (1987). The biology of Gyrodactylus gallieni (Gyrodactylidea), an unusual viviparous monogenean from the African clawed toad, Xenopus laevis. J. Zool., Lond. 212: 325-346

Heggberget, T G., Johnsen, B. O. (1982). Infestations by Gyrodactylus sp. of Atlantic salmon, Salmo salar L., in Norwegian rivers. J. Fish Biol. 21: 15-26

Hoffman, G. L., Putz, R. E. (1964). Studies on Gyrodactylus macrochiri n. sp. (Trematoda: Monogenea) from Lepomis macrochirus. Proc. Helminth. Soc. Wash. 31: 76-82

Holmes, J. C. (1979). Parasite populations and host community structure. In: Nickol, B. B. (ed.) Host parasite interfaces. Academic Press, New York, p. 27-46

Jakubowski, M. (1960). The structure and vascularization of the skin of the eel (Anguilla anguilla L.) and the viviparous blenny (Zoarces viviparus L.). Acta biol. Cracov., Ser. Zool. 3: $1-22$

Jansen, P. A., Bakke, T A. (1991). Temperature-dependent reproduction and survival of Gyrodactylus salaris Malmberg, 1957 (Platyhelminthes: Monogenea) on Atlantic salmon (Salmo salar L.). Parasitology 102: 105-112

Jansen, P. A., Bakke, T. A., Hansen, L. P. (1991). Resistance to Gyrodactylus salaris Malmberg, 1957 (Monogenea) in Salmo salar: a genetic component. Bull. Scand. Soc. Parasitol. 1: 50

Johnsen, B. O. (1978). The effect of an attack by the parasite Gyrodactylus salaris on the population of salmon parr in the river Lakselva, Misvaer in northern Norway. Astarte 11: $7-9$

Johnsen, B. O., Jensen, A. J. (1985). Parasitten Gyrodactylus salaris på lakseunger i norske vassdrag, statusrapport. Direktoratet for Vilt og Ferskvannsfisk, Reguleringsundersøkelsene. Rapport nr. 2: 1-145 (In Norwegian)

Johnsen, B. O., Jensen, A. J. (1986). Infestations of Atlantic salmon, Salmo salar, by Gyrodactylus salaris in Norwegian rivers. J. Fish Biol. 29: 233-241

Johnsen, B. O., Jensen, A. J. (1988). Introduction and establishment of Gyrodactylus salaris Malmberg, 1957, on Atlantic salmon Salmo salar L., fry and parr in the river Vefsna, northern Norway. J. Fish Dis. 11: 35-45

Johnsen, B. O., Jensen, A. J. (1991). The Gyrodactylus story in Norway. Aquaculture 98: 289-302

Johnsen, B. O., Jensen, A. J., Sivertsen, B. (1989). Extermination of Gyrodactylus salaris-infected Atlantic salmon Salmo salar by rotenone treatment in the river Vikja, western Norway. Fauna Norv. (Ser. A) 10: 39-43

Kalleberg, H. (1958). Oberservations in a stream tank of territoriality and competition in juvenile salmon and trout (Salmo salar L. and Salmo trutta L.). Rep. Inst. Freshwat. Res. Drottningholm 39: 55-98

Kamiso, H. N., Olson, R. E. (1986). Host-parasite relationships between Gyrodactylus stellatus (Monogenea: Gyrodactylidae) and Parophrys vetulus (Pleuronectidae - English sole) from the coastal waters of Oregon. J. Parasitol. 72: $125-129$

Kearn, G. C. (1967). Experiments on host-finding and hostspecificity in the monogenean skin parasite Entobdella soleae. Parasitology 57: 585-605

Kearn, G. C. (1986). The eggs of the monogeneans. Adv. Parasitol. 25: 175-273

Konovalov, S. M. (1967). Monogenetic trematodes from fishes in the Amur river system. Tr. Zool. Inst. Akad. Nauk SSSR
19: 171-399 (In Russian)

Kulemina, I. V. (1979). Dispersal of Gyrodactylidea from freshwater. In: VII Vsesoyuznoe Soveshchanie po parazitam i boleznyam ryb, Leningrad 1979. Tezisy dokladov. Nauka, Leningrad, p. 59-61 (In Russian)

Lester, R. J. G. (1972). Attachment of Gyrodactylus to Gasterosteus and host response. J. Parasitol 58: 717-722

Llewellyn, J. (1984). The biology of Isancistrum subulatae n. sp., a monogenean parasitic on the squid, Alloteuthis subulata, at Plymouth. J. mar. biol. Ass. U.K. 64: 285-302

Lubbock, R. (1979). The downfish/anemone symbiosis: a problem of cellular recognition. Parasitology 82: 159-173

Lucky, Z. (1963). Fund der Art Gyrodactylus salaris Malmberg, 1956 auf der Haut der Regenbogenforelle (Trutta gairdneri irideus Gibbons, 1855). Sb. Vys. Sk. Zemed. Brne, Rada B: Spis. Vet. 11: 127-130 (In Czechoslovakian, German summary)

Lux , E. (1990). Gyrodactylus salaris-parasitierung von Salmoniden, ein diagnostisch-taxonomisches Problem. In: Bernoth, E.-M., Hoffmann, R. (eds.) Tagung der Fachgruppe 'Fischkrankheiten' in Verbindung mit der EAFP/deutsche Sektion European Association of Fish Pathologists. Deutsche Veterinärmedizinische Gesellschaft e. V., Giessen, p. 87-98

Lyons, K. M. (1969a). Sense organs of monogenean skin parasites ending in a typical cilium. Parasitology 59:611-623

Lyons, K. M. (1969b). Compound sensilla in monogenetic skin parasites. Parasitology 59:625-636

MacKenzie, K. (1970). Gyrodactylus unicopula Glukhova, 1955, from young plaice Pleuronectes platessa L. with notes on the ecology of the parasite. J. Fish Biol. 2: 23-34

Madhavi, R., Anderson, R. M. (1985). Variability in the susceptibility of the fish host, Poecilia reticulata, to infection with Gyrodactylus bullatarudis (Monogenea). Parasitology 91: $531-544$

Malmberg, G. (1957). Om forekomsten av Gyrodactylus på svenska fiskar. Skr. söd. Sver. FiskFör. Årsskr. 1956: 19-76 (In Swedish)

Malmberg, G. (1970). The excretory systems and the marginal hooks as a basis for the systematics of Gyrodactylus (Trematoda, Monogenea). Ark. Zool. 23: 1-235

Malmberg, G. (1972). On spreading of ectoparasites on fish to new areas and in fish cultures. Symposium on Spreading of Parasites, 13-14 Dec 1972. Scandinavian Society of Parasites, Copenhagen, p. 1-3

Malmberg, G. (1973). On a Gyrodactylus species from northern Sweden and the subgeneric position of $G$. hrabei Ergens, 1957 (Trematoda, Monogenea). Zool. Scr. 2: $39-42$

Malmberg, G. (1974). On the evolution within Gyrodactylidae (Monogenoidea). Proc. 3rd Int. Congr. Parasit., Munich. Vol. 1. Facta Publication, Verlag H. Egermann, Vienna, p. $330-331$

Malmberg, G. (1987a). Gyrodactylus - en haptormask av ekonomiskt interesse for fiskodlare. Vattenbruk 2: 15-20 (In Swedish)

Malmberg, G. (1987b). Gyrodactylus salaris Malmberg, 1957 and G. truttae Gläser, 1974 - two problematic species. In: Actual problems in fish parasitology. 2nd Int. Symp. Ichthyoparasit., Tihany, Hungary, p. 56

Malmberg, G. (1988). Gyrodactylus salaris-infeksjoner, laxfisk-transporter och odling i Norden. Vattenbruk 2: $22-24,26-29$ (In Swedish)

Malmberg, G. (1989a). On Gyrodactylus and Pseudodactylogyrus in natural waters and fish farms. Åbo Akademi, Information 20:46

Malmberg, G. (1989b). Salmonid transports, culturing and 
Gyrodactylus-infections in Scandinavia. In: Parasites of fresh-water fishes of North-west Europe. Inst. Biol. USSR Acad. Sci, Karelian Branch, Petrozavodsk 1989, p. 88-104

Malmberg, G., Malmberg, M. (1970). Dactylogyrus och Gyrodactylus - två vanliga parasiter på svenska fiskar. Zool. Revy 32: 9-18 (In Swedish, English Summary)

Malmberg, G., Malmberg, M. (1991). Undersökningar angående Gyrodactylus på laxfisk i fria vatten och odlingar under åren 1951 - 72 och 1986 - maj 1991. Inf. Sötvattenslab., Drottningholm 2: 1-30 (In Swedish, English summary)

Margolis, L., Arthur, J. R. (1979). Synopsis of the parasites of fishes in Canada. Bull. Fish. Res. Bd Can. 199: 1-269

May, R. M., Anderson, R. M. (1978). Regulation and stability of host parasite population interactions. 2. Destabilizing processes. J. Anim. Ecol. 47: 248-269

Mikailov, T. K. (1975). Parasites of fish in the Azerbaidzhana Reservoir. Acad. Sci., Azerbaidzhanskoi SSR, Izdatelstvo 'Elm', Baku (In Russian)

Mo, T. A. (1983). Gyrodactylus truttae Gläser, 1974 på ørret, Salmo trutta L. og laks, Salmo salar L. i Sandviksvassdraget. Cand. real. thesis, University of Oslo, Oslo (In Norwegian)

Mo, T A. (1987). Taxonomiske og biologiske undersøkelser. Virksomheten i 1986 og forslag til virksomheten i 1987. Gyrodactylus-undersøkelsene ved Zoologisk Museum, Universitetet i Oslo. Rapport nr. 2: 1-69 (In Norwegian)

Mo, T. A. (1988). Virksomheten i 1987 og program for virksomheten i 1988. Gyrodactylus-undersøkelsene ved Zoologisk Museum, Universitetet i Oslo. Rapport nr. 4: 1-29 (In Norwegian)

Mo, T. A. (1989). Fiskeparasitter i slekten Gyrodactylus forårsaker problemer for oppdrett og forvaltning. Norsk VetTidsskr. 101: 523-527 (In Norwegian, English summary)

Musselius, V. A. (1988). Monogeneans of fish farms and their importance in the modern methods of pisciculture. In: Skarlato, O. A. (ed.) Investigations of monogeneans in the USSR. A. A. Balkema, Rotterdam, p. 143-151 (Russian translations series 62)

Nicola, K. J., Cone, D. K. (1987). Description of Gyrodactylus micropteri n. sp. from Micropterus dolomieui in Lake Huron, with a review of the taxonomy of species of Gyrodactylus (Monogenea) parasitizing centrarchid fishes in North America. Can. J. Zool. 65: 1337-1339

O'Rourke, F. J. (1961). Presence of blood antigens in fish mucus and its possible parasitological significance. Nature, Lond. 189: 943

Parker, J. D. (1965). Seasonal occurrence, transmission, and host specificity of the monogenetic trematode Gyrodactylus elegans from the golden shiner (Notemigonus crysoleucas). Ph.D. thesis, Southern Illinois University

Prudhoe, S., Bray, R. A. (1982). Platyhelminth parasites of the Amphibia. British Museum (N.H.), Oxford University Press

Responsible Subject Editor: W. Körting, Hannover, Germany
Putz, R. E., Hoffman, G. L. (1963). Two new Gyrodactylus (Trematoda: Monogenea) from cyprinid fishes with synopsis of those found on North American fishes. J. Parasitol. 49: $559-566$

Rawson, H. V. Jr, Rogers, W. A. (1973). Seasonal abundance of Gyrodactylus macrochiri Hof man \& Putz, 1964 on bluegill and largemouth bass. J. Wildl. Dis. 9: 174-177

Rehulka, J. (1973). Remarks on the occurrence of Gyrodactylus salaris Malmberg, 1957 sensu Ergens, 1961 (Monogenoidea: Gyrodactylidae). Vestn. Cesk. Spol. Zool. 37: $293-295$

Saunders, R. L., Gee, J. H. (1964). Movements of young Atlantic salmon in a small stream. J. Fish. Res. Bd Can. 21 $27-36$

Scott, M. E. (1982). Reproductive potential of Gyrodactylus bullatarudis (Monogenea) on guppies (Poecilia reticulata). Parasitology 85: 217-236

Scott, M. E., Anderson, R. M. (1984). The population dynamics of Gyrodactylus bullatarudis (Monogenea) within laboratory populations of the fish host Poecilia reticulata. Parasitology 89: 159-194

Soleng, A., Bakke, T. A. (1991). Experimental studies on the salinity tolerance of Gyrodactylus salaris Malmberg, 1957. Bull. Scand. Soc. Parasitol. 1: 79

Solomatova, V. P., Luzin, A. V. (1988). Gyrodactylosis of carps in fish tanks located on discharged waters of the Kostromsk electric power plant and some problems of the biology of Gyrodactylus katharineri. In: Skarlato, O. A (ed.) Investigation of monogeneans in the USSR. Oxonian Press Prt. Ltd, New Delhi, p. 163-168 (Russian translation series 62)

Srivastava, L. P., James, B. L. (1967). The morphology and occurrence of Gyrodactylus medius Kathariner, 1894 (Monogenoidea) from Onos mustelus L. J. nat. Hist. 4: $481-489$

Symons, P. E. K. (1976). Behavior and growth of juvenile Atlantic salmon (Salmo salar) and three competitors at two stream velocities. J. Fish. Res. Bd Can. 33: 2766-2773

Tanum, K. (1983). Studier av taksonomi og vertsforhold hos Gyrodactylus-arter på laksefisk av slektene Salmo og Salvelinus i Norge. Cand. scient. thesis, University of Oslo (In Norwegian)

Wood, R. A., Mizelle, J. D. (1957). Studies on monogenetic trematodes. XXI. North American Gyrodactylinae, Dactylogyrinae and a new host record for Urocleidus dispar (Mueller, 1936). Am. Midl. Nat. 57. 183-202

Zitnan, R. (1960). Gyrodactylus thymalli sp. nov. aus den Flossen der Äsche (Thymallus thymallus L.). Helminthologia (Bratisl.) 5: 49-51

Zitnan, R., Cankovic, M. (1970). Comparison of the epizootological importance of the parasites of Salmo gairdneri irideus in the two coast areas of Bosna and Herzegovina. Helminthologia (Bratisl.) 11: 161-166

Manuscript first received: July 20, 1991

Revised version accepted: February 14, 1992 